\title{
The role of social skills in burnout and engagement among university students
}

\section{Heli Kiema-Junes ${ }^{1}$, Mirka Hintsanen ${ }^{1}$, Hannu Soini ${ }^{1}$ and Kirsi Pyhältö ${ }^{2}$}

${ }^{1}$ Faculty of Education, University of Oulu

${ }^{2}$ Faculty of Education, University of Helsinki

Finland

Correspondence: Heli Kiema-Junes. Faculty of Education, University of Oulu, Finland. Email:heli.kiema@oulu.fi

(C) Universidad de Almería and Ilustre Colegio Oficial de la Psicología de Andalucía Oriental (Spain) 


\begin{abstract}
Introduction. Social skills may prevent burnout and enhance engagement in students by increasing social support and improving relationships with peers and teachers.

Method. This study explores the interrelation between self-reported social skills and experienced burnout and engagement among 351 university students (70.5\% women, $29.5 \%$ men) in different study fields. The Study Burnout Inventory (SBI-9), the Utrecht Work Engagement Scale-Student (UWES-S) and a social skills questionnaire were utilised. The data was analysed using linear regression analysis.
\end{abstract}

Results. The results show an association between higher social skills and lower burnout and higher engagement. Higher engagement was also associated to lower burnout.

Discussion and Conclusion. The findings imply that targeting social skills might offer a way to increase engagement and diminish burnout among students.

Keywords: burnout, engagement, university students, higher education, social skills 


\section{Resumen}

Introducción. Las habilidades sociales pueden evitar el agotamiento y mejorar la participación en los estudiantes al aumentar el apoyo social y mejorar las relaciones con sus compañeros y maestros.

Método. Este estudio explora la interrelación entre las habilidades sociales autoinformadas y el agotamiento experimentado y el compromiso entre 351 estudiantes universitarios $(70.5 \%$ mujeres, 29.5\% hombres) en diferentes campos de estudio. Se utilizaron el Study Burnout Inventory (SBI-9), la Utrecht Work Engagement Scale-Student (UWES-S) y un cuestionario de habilidades sociales. Los datos se analizaron mediante análisis de regresión lineal.

Resultados Los resultados muestran una asociación entre mayores habilidades sociales y menor agotamiento y mayor compromiso. Un mayor compromiso también se asoció a un menor agotamiento.

Discusión y conclusión. Los hallazgos implican que enfocarse en las habilidades sociales podría ofrecer una forma de aumentar el compromiso y disminuir el agotamiento entre los estudiantes.

Palabras clave: agotamiento, compromiso, estudiantes universitarios, educación superior, habilidades sociales. 


\section{Introduction}

Engagement plays a significant role in academic success and working life. It is regarded as a hallmark of an optimal study experience (Bilge, Tuzköl, Dost, \& Cetin, 2014), with engaged students usually completing their studies successfully (Kuh, Kinzie, Buckley, Bridges, \& Hayek, 2007; Salanova, Schaufeli, Martinez, \& Breso, 2010). Engaged university students also have high study motivation (Cazan, 2015; Stoeber, Childs, Hayward, \& Feast, 2011) and better self-esteem (Forsyth, Lawrence, Bernetti, \& Baumeister, 2007). However, a number of higher education students face serious problems in their studies. If prolonged, these students are in a risk developing stress and, eventually, burnout (Schaufeli \& Salanova, 2007; Schaufeli, Salanova, Gonzales-Roma, \& Bakker, 2002). Study-related burnout has been on the rise in the last decade (Schaufeli, Martinez, pinto, Salanova, \& Bakker, 2002) and a significant proportion of higher education students have been shown to suffer from study-related stress and burnout during their university studies (Salmela-Aro, Kiuru, Leskinen, \& Nurmi, 2009).

Burnout and reduced engagement can cause problems for higher education students, as well as for education institutions, because they are associated with low academic performance (Schaufeli et al., 2002; Galbraith \& Merril, 2015) and low academic motivation (Lyndon et al., 2017). Burnout can cause problems for students in transition to work life as student burnout predicts burnout at work in the dimensions of exhaustion and cynicism (Robins, Roberts, \& Sarris, 2018). Engaged students succeed in their studies, while burned-out students are more likely to fail or even dropout (Salmela-Aro, Savolainen, \& Holopainen, 2009). Social skills are one potential factor influencing student engagement, but it has largely been overlooked in the literature. This study explores the role of social skills in study burnout and engagement.

\section{Students' burnout}

Students do not always cope optimally with study challenges, which can cause stress, and eventually, burnout. Study-related burnout is a syndrome of three distinctive symptoms: exhaustion, cynicism and inefficacy (Salmela-Aro et al., 2009; Schaufeli et al., 2002). Emotional exhaustion refers to the feeling of being emotionally exhausted from study work; whereas cynicism denotes a cynical attitude towards studying and inefficacy measures feelings of inadequacy as a student (Maslach \& Leiter, 2005; Salmela-Aro et al., 2009). Study 
burnout is associated with low academic achievement (Galbraith \& Merril, 2015), low academic self-esteem (Schöne, Tandler, \& Stiensmeier-Pelster, 2015) and low performancebased self-esteem (Dahlin, Juneborg, \& Runeson, 2007). High levels of burnout among students is also related to lower self-perception skills (Rodriguez-Hidalgo, Calmaestra, \& Dios, 2014).

Imbalances between study and paid work and feeling pressured can cause stress, or students can set overly high performance-related goals, becoming stressed from lack of achievement (Schouwenburg, 2004; Salmela-Aro \& Kunttu, 2010), which can result in student burnout (Salmela-Aro et al., 2009). Excessive demands in school can lead to increasing difficulty in coping with such demands, which can result in stress and pressure (Friesen \& Sarros, 1989). Study-related burnout arises from feelings of strain, especially fatigue over one's schoolwork (Salmela-Aro et al., 2009). Prolonged feelings of exhaustion can contribute to a cynical attitude towards studies, resulting in a loss of interest in academic work (SalmelaAro et al., 2009). Burnout and engagement are seen as independent dimensions, but they are negatively correlated (Schaufeli \& Bakker, 2004). It is also worth noting the gender differences in stress and burnout; young women tend to suffer from stress (Reiseberg, 2000) and burnout (Kiuru, Aunola, Nurmi, Leskinen, \& Salmela-Aro, 2009) more than young men even though women are performing better at school than men (Pomerantz, Altermatt, \& Saxon, 2002). Salmela-Aro and Read (2017) point out that students' risk of burnout rises along increasing study years.

\section{Student's engagement}

Study-related engagement refers to a positive emotional state of student well-being characterised by vigour, dedication and absorption (Schaufeli \& Bakker, 2004; Schaufeli et al., 2002). Vigour denotes high levels of energy and mental resilience while working, putting in effort and being persistent about one's work. Dedication connotes a sense of significance, enthusiasm, inspiration and pride in one's studies and finding study work challenging enough (Schaufeli et al., 2002). Absorption is characterised by being concentrated and happily engrossed in one's study work (Schaufeli et al., 2002). Absorption may feel like time is passing quickly, with a student being captivated by his/her study (Schaufeli et al., 2002).

An optimistic attitude, enthusiasm and commitment to studies are regarded as factors that increase study engagement (Salmela-Aro \& Kunttu, 2010). Positive feelings about one's 
study field, spending extra time with study work, determining one's own learning objectives and feelings of accomplishment and self-efficacy can also foster the possibility of study engagement (Bilge et al., 2014). Study engagement is also associated with high personal standards (Zhang, Gan, \& Cham, 2007), academic performance (Breso, Schaufeli, \& Salanova, 2010; Vizoso, 2018), effective coping strategies and lower levels of perceived stress (Gan, Yang, Zhou, \& Zhang, 2007). There are gender differences in engagement; previous studies show that girls are more engaged at school than boys, and teacher support partly explains the gap in engagement between boys and girls (Liataert, Roorda, Leavers, Verschueren, \& De Fraine, 2015). Study engagement seems to have a great influence on transition to university as it is well known that age and the year of studies have an effect on engagement (Ayala \& Manzano, 2018) and students seem to be more engaged in the early years of their studies (SalmelaAro \& Read, 2017).

\section{Social skills among students}

Social interactions have been suggested to play a central role in the development of both study-related burnout and engagement (Halbesleben \& Buckley, 2006; Wang \& Eccles, 2012). Social skills refer to the ability to behave according to the environmental requirements of the social context in which interpersonal relationships occur (Bakx, Van Der Sanden, Sijitsma, Croon, \& Vermetten, 2006). They entail the ability to integrate feelings and thoughts and to express behaviours according to personal goals in a particular context and culture (Ford, 1982). Good social skills enable a student to interact effectively with other people, which is related to many positive psychological and social consequences (Segrin, Hanzal, Donnerstein, Taylor, \& Domschke, 2007).

Social skills are associated with perceived social support (Riggio, Watring, \& Throckmorton, 1993), which is shown to decrease burnout (Jacobs \& Dodd, 2003; Kutsal \& Bilge, 2012) and improve school engagement (Wang \& Eccles, 2012). Moreover, a sense of belonging to the study group, positive relationships with other students and staff, participation in extra-curricular activities and being able to participate in conversation and decision making in the class all influence study engagement (Bilge et al., 2014). Conversely, a negative study atmosphere and insufficient study guidance can increase the risk of experiencing study burnout (Salmela-Aro, Savolainen, \& Holopainen, 2009). 
Social skills increase social competence and emotional and behavioural adjustment (Spence, 2003). Thus, it seems plausible that social skills may be associated wth lower risk of burnout and increased engagement. Social competence is the ability to integrate behavioural, cognitive and affective skills to obtain successful outcomes from interactions with others (Bierman \& Welsh, 2000). Social skills also increase the amount and quality of social support, which is strongly associated with one's personal resources (Siedlecki, Salthouse, Oishi, \& Jeswani, 2014), which in turn is closely related to well-being (Xanthoupoulou, Bakker, Demerouti, \& Schaufeli, 2009). Students with good social skills tend to have higher selfesteem, more social support, higher life-satisfaction (Cooley, Buren, \& Cole, 2011; Malinauskas, Dumciene, \& Lapeniene, 2014; Riggio, Thorckmorton, \& Depaola, 1990) and better academic functioning (Demaray \& Elliot, 2001).

Social skills are also associated with satisfying interpersonal relations, which in turn promote health, personal satisfaction and quality of life (Del Prette \& Del Prette, 2013). Social skills are negatively correlated with social anxiety, loneliness and depression (Riggio et al., 1990; Segrin, 1993) and positively correlated with increased academic success and effective stress regulation (Luthar, 1991; Zach, Yazdi-Ugav, \& Zeev 2016).

\section{Relationship among engagement, burnout and social skills}

Social support (Riggio et al., 1993) has been proposed to buffer the risk of studyrelated burnout (Cobb, 1976; Emadpoor, Lavasani, \& Shacheraghi, 2016; Civitsi, 2015; Halbesleben \& Buckley, 2006) and foster study-related engagement (Lamonte et al., 1995; Kantanis, 2000). Social skills are positively correlated with perceived social support, and social skills combined with social support predict satisfaction and adjustment in college students (Riggio et al., 1993). Social aspects of the teaching-learning environment are also linked to the level of study-related burnout. Research indicates that the more negative perceptions students have of the learning environment, the higher the level of experienced study-related burnout is (Meriläinen \& Kuittinen, 2014).

Social skills are negatively correlated with components of burnout in medical residents (Pereira-Lima \& Loureiro, 2015), and it has been suggested that social skills may act as protective factors against burnout and other mental health problems such as anxiety and depression (Pereira-Lima \& Loureiro, 2015). However, the research about the role of social skills in burnout and engagement is almost completely lacking among higher education students. 
There is only one study describing the role of social skills in burnout among medical residents (Pereira-Lima \& Loureiro, 2015) so there is definitely a need for further studies with relation to higher education students and the role of social skills in study engagement as well. While there is limited research about the relation between social skills and burnout, social support has repeatedly been shown to buffer the risk of study burnout (Emadpoor, Lavasani, \& Shahcheraghi, 2016; Civitsi, 2015; Halbesleben \& Buckley, 2006; Jacobs \& Dodds, 2003). We know very little about the role of social skills in engagement and burnout among higher education students. Arguably, social skills that enable students to better relate to and modify their study environment can reduce the risk of experiencing burnout and, thus, increase engagement.

\section{Objectives and Hypotheses}

In this study, we examine the role of social skills in student burnout and student engagement among university students. We hypothesise that higher social skills are associated with lower burnout and higher engagement among students. We also report on the association between study-related burnout and engagement (Salmela-Aro \& Upadyaya, 2014; Salanova et al., 2009; Schaufeli et al., 2002). We adjust for gender and age as they may act as potential confounders.

\section{Methods}

\section{Participants}

The study included 351 students $(70.5 \%$ female and $29.5 \%$ men, approximately $70 \%$ of course attendants) from various years and degree programmes in seven departments at the University of Oulu: $46.3 \%$ from education, $20.8 \%$ humanities, $17.4 \%$ science, $3.9 \%$ medicine, $6.6 \%$ economics, $2.4 \%$ technology and $1.2 \%$ information technology. Their age varied from 19 to 44 years, and their civil status varied as follows: $5.4 \%$ single, $3.1 \%$ in a relationship, $19.7 \%$ cohabitating, $0.8 \%$ engaged, $13.9 \%$ married, $29.3 \%$ unmarried, $0.4 \%$ divorced and $0.4 \%$ single parents. All the students were Caucasians.

\section{Instruments}

The students were asked questions about study engagement (Utrecht Work Engagemens Scale for Students, UWES-S), as well as to fill out the burnout surveys (Study Burnout Inventory, SBI-9), and students were also asked to self-rate their social skills. 


\section{Study-related engagement}

To measure engagement in students, we used the Utrecht Work Engagement ScaleStudents (UWES-S; Schaufeli et al., 2002), which comprises nine items ( $\alpha=.91$ ), of which, three measure vigour ( $\alpha=.79$, "when I study, I feel like I am bursting with energy"), three dedication ( $\alpha=.85$, "I find my studies to be full of meaning and purpose") and three absorption ( $\alpha=$.76, "time flies when I'm studying") (Schaufeli et al., 2002). The students responded to all items on a six-point scale from $1=$ strongly disagree to $6=$ strongly agree. The scale's reliability and validity among university students has been verified in previous research (Breso, Schaufeli, \& Salanova 2011; Mostert et al., 2007; Schaufeli et al., 2002; Uludag \& Yaratan, 2010). The study engagement scale has also been validated in a study environment in higher education in Finland (Salmela-Aro et al., 2009). The construct validity of the scale has previously been examined with structural equation modelling (SEM) : The model showed strong inner compatibility for the scale and it fitted well to the data and can be well applied to examining student engagement (Schaufeli et al., 2002). Mean variable was utilised in our analyses.

\section{Study-related burnout}

To measure burnout in students, we used the Finnish version of the Study Burnout Inventory (SBI-9; Salmela-Aro et al., 2009), which is similar to the original Maslach Burnout Inventory - Student Survey (MBI-SS) by Schaufeli et al. (2002). The inventory comprises nine items $(\alpha=.84)$ of three-factor structure based on the MBI-GS (Maslach Burnout Inventory - General Survey), of which four measure exhaustion $(\alpha=.75$, "I feel emotionally drained by my studies"), three cynicism ( $\alpha=.82$, "I have become less enthusiastic about my studies"), and two inefficacy ( $\alpha=.60$, "I have often feelings of inadequacy in my studies") (Schaufeli et al., 2002; Salmela-Aro et al., 2009). Burnout can be examined with different factor models such as one-factor, two-factor and three-factor models but confirmatory analysis has shown that three-factor model had the best fit to the data and was clearly better to the one and twofactor models (Schutte, Toppinen, Kalimo, \& Schaufeli, 2000). Although inefficacy did not show as strong reliability as the other dimensions, the three-factor model is aligned with the theory and gives more specific information about students' burnout symptoms (Schaufeli et al., 2002) than the one or two-factor models. The students responded to all items on a sixpoint scale from $1=$ strongly disagree to $6=$ strongly agree. The scale's reliability and validity in university students has been verified in previous research (Breso, Schaufeli, \& Salanova, 
2011; Mostert, Pienaar, Gauche, \& Jackson, 2007; Schaufeli et al., 2002; Uludag \& Yaratan, 2010). The construct validity of the measure has been examined with structural equation modelling among Finnish higher education students (Salmela-Aro et al., 2009) and the results indicated that the scale has strong inner compatibility and the reliability was strong for all components of burn out (Salmela-Aro et al., 2009). A mean score of the scale was used in analyses.

\section{Social skills}

We also asked the students to self-rate their social skills by means of a questionnaire, which included six items ( $\alpha=.76$, e.g. "I find it difficult to argue my opinions in a group situation", "When I express my opinions, people listens to me", "I need advice and education with social skills", "I am able to argue my opinions rationally in group situations", "I have good social skills" and "Peers tell and trust me with difficult issues") of self-evaluated perceptions regarding their social skills level. We run factor analysis for the questionnaire items and items loaded on two factors. Six items loaded on the first factor and this factor explained $38.66 \%$ of the variation. Only two items loaded on the other factor. Item ("I give advice as often as it is possible") received low loadings on both factors (.16 and .17) and was, thus removed. The only remaining item ("I consider myself as a good listener") of the second factor had a low loading with the first factor (.12) and also differed in content from the items on the first factor and was thus not included in the final scale. The six items used in this study loaded in the same factor $(\alpha=.76)$. The background of the questionnaire is based on the theoretical frames of specific communication skills such as the Human Relations Counselling Model (HRCM, Okun, 2002), micro-counselling (Ivey, 1971; Ivey \& Ivey, 2007) and human resource development (HRD, Truax \& Carkhuff, 1967) that highlight specific social skills. Studies have shown that focusing on these specific skills enhances social skills in counselling sessions (Baker \& Daniels, 1989, 1990; Buser, 2008). The questionnaire focuses also to similar classes as Social Skills Inventory (SSI-Del-Prette, Del Prette \& Del Prette, 2013) as communication, assertive, empathetic, work (coordinating social interaction situations), and expression of positive feelings. We used mean scores of the scale for our analyses.

\section{Procedure}

The study was executed in 2013-2016 during an educational psychology course in basic studies and an organisational psychology course in advanced studies, which were part of a study programme in educational psychology at the University of Oulu. We selected these 
courses because of their heterogeneity of participants, with students from different faculties attending. The participants took part in the above-mentioned at the university during the years 2013, 2014, 2015 and 2016. The students invited to answer the questionnaire were attending educational psychology and organizational psychology courses in basic and advanced studies in educational psychology. Students received the information about the questionnaire and study and were able to choose whether to participate or not. They were able to fill the questionnaire either by paper or online. A paper version of the survey was used by approximately three thirds of the participants, and one third filled out the online version. The students received no payment for their contribution. The students were not asked to fill their names on the questionnaire, and they could remain anonymous.

\section{Statistical Analysis}

We examined the interaction between gender and social skills, with study burnout and study engagement as dependent variables (separate analyses). We also checked the interaction between gender and engagement, with burnout as the dependent variable. The interaction between gender and social skills, with study burnout as the dependent variable, was significant $(p=<.05)$. All other gender interactions were non-significant.

Age- and gender-adjusted linear regression analyses were conducted to examine 1) associations of social skills with study engagement and burnout and 2) the association between study-related engagement and burnout. Hierarchical linear regression analyses were run for burnout and study engagement. We used gender and age as control variables. Social skills was set as the independent variable and study engagement and burnout were used as dependent variables. In the analyses on the associations between engagement and burnout, engagement was set as the independent variable and burnout as the dependent variable. Age and gender were used as control variables in all our analyses. The independent variables were introduced to the regression analysis with method enter. We also used social skills as control variable in analyses between engagement and burnout. 


\section{Results}

Table 1. Descriptive Statistics of the Study Sample

\begin{tabular}{lcccc}
\hline \multicolumn{1}{c}{ Variable } & Mean & SD & Number & \% \\
\hline Age $^{\text {a }}$ & 24.26 & 5.9 & & \\
Gender $^{\text {a }} \quad$ & & & & \\
$\quad$ Women & & & 251 & 70.5 \\
$\quad$ Men & & & 74 & 29.5 \\
$\quad$ Study engagement (1-6) & 4.02 & 0.77 & & \\
Vigour (1-6) $^{\mathrm{a}}$ & 3.94 & 0.84 & & \\
Dedication (1-6) $^{\mathrm{a}}$ & 4.56 & 0.84 & & \\
Absorption (1-6) $^{\mathrm{a}}$ & 3.57 & 0.92 & & \\
Study burnout (1-6) $^{\mathrm{a}}$ & 2.64 & 0.82 & & \\
Exhaustion (1-6) $^{\mathrm{a}}$ & 2.95 & 0.92 & & \\
Cynicism (1-6) $^{\mathrm{a}}$ & 1.96 & 0.96 & & \\
Inefficacy (1-6) $^{\mathrm{a}}$ & 3.00 & 1.11 & & \\
Social skills (1-6) $^{\mathrm{b}}$ & 4.56 & 0.60 & & \\
\hline
\end{tabular}

${ }^{\mathrm{a}} \mathrm{N}=351,{ }^{\mathrm{b}} \mathrm{N}=319$

Bivariate associations (Pearson correlations) between the study variables are presented in Table 2. Social skills correlated with lower burnout $(r=-.31, p<.001)$ and higher study engagement $(r=.19, p<.001)$. Engagement correlated with lower study burnout $(r=-.58$, $p<.001)$. The dimensions of study burnout and study engagement were also correlated. Cynicism correlated with lower dedication $(r=-.62, p<.001)$ and lower vigour $(r=-.59, p<.001)$, while inefficacy correlated with lower vigour $(r=-.51, p<.001)$. 


\begin{tabular}{|c|c|c|c|c|c|c|c|c|c|c|}
\hline & 1. & 2. & 3. & 4. & 5. & 6. & 7. & 8. & 9. & 10. \\
\hline 1. Gender ${ }^{\mathrm{a}}$ & 1 & & & & & & & & & \\
\hline 2. Age & $-.12 *$ & 1 & & & & & & & & \\
\hline 3. Social skills & .11 & $-.19 * *$ & 1 & & & & & & & \\
\hline 4. Study engagement & $.12 *$ & $.24 * *$ & $.19 * *$ & 1 & & & & & & \\
\hline 5. Vigour & .08 & $.15^{* *}$ & $.18^{* *}$ & $.90^{* *}$ & 1 & & & & & \\
\hline 6. Dedication & $.15^{* *}$ & $.21 * *$ & $.26^{* *}$ & $.88 * *$ & $.71^{* *}$ & 1 & & & & \\
\hline 7. Absorption & .10 & $.27 * *$ & .08 & $.88 * *$ & $.70^{* *}$ & $.64 * *$ & 1 & & & \\
\hline 8. Study burnout & -.03 & $-.13 *$ & $-.31 * *$ & $-.58 * *$ & $-.60 * *$ & $-.51 * *$ & $-.42 * *$ & 1 & & \\
\hline 9. Exhaustion & -.03 & $-.12 * *$ & $-.17 * *$ & $-.26^{* *}$ & $-.39 * *$ & $-.22 * *$ & $-.19 * *$ & $.76^{* *}$ & 1 & \\
\hline 10. Cynicism & $-.15 * *$ & -.07 & $-.35 * *$ & $-.61 * *$ & $-.59 * *$ & $-.62 * *$ & $-.42 * *$ & $.80 * *$ & $.40 * *$ & 1 \\
\hline 11 Inefficacy & .00 & $-.12 *$ & $-.24 * *$ & $-.50 * *$ & $-.51 * *$ & $-.41 * *$ & $-.41 * *$ & $.87 * *$ &, $54 * *$ & $.56^{* *}$ \\
\hline
\end{tabular}

Table 2. Bivariate Correlations

$* * \mathrm{p}<.01 ; * \mathrm{p}<.05,{ }^{\mathrm{a}}$ male $=0$, female $=1$

Age- and gender-adjusted linear regression analyses showed associations between social skills and burnout $(B=-.50, p=<.001)$ and between social skills and engagement $(B=$ $.30, p=<.001$ ). Social skills explained $13 \%$ of burnout and $6 \%$ of engagement. Age- and gender-adjusted linear regression analysis also showed associations between social skills and exhaustion $(B=-.26, p=<.005)$, cynicism $(B=-.67, p=<.001)$ and inefficacy $(B=-.56$, $p<.001)$. The analysis also yielded associations between social skills and vigour $(B=.28, p=$ $<.001)$, dedication $(B=.46, \mathrm{p}<.001)$ and absorption $(B=.19, p=<.01)$. Social skills explained $3 \%$ of the variation in exhaustion, $14 \%$ in cynicism and $7 \%$ in inefficacy. Social skills also explained $4 \%$ of the variation in vigour, $11 \%$ in dedication and $2 \%$ in absorption.

Study engagement was also associated with study burnout $(B=-.63, p<.001)$ in the age- and gender-adjusted regression analyses. To analyse whether social skills explained the 
association between engagement and burnout, we also adjusted for social skills. The association between engagement and study burnout remained significant.

Table 3. Linear Regression on the Associations between Social Skills and Study Engagement and Burnout

\begin{tabular}{|c|c|c|c|c|}
\hline & Study burnout & Exhaustion & Cynicism & Inefficacy \\
\hline \multirow{3}{*}{ Social skills } & $\begin{array}{lll}B & S E & \text { Adj. } R^{2} R^{2} \text { change } p\end{array}$ & $\begin{array}{lll}B & S E & \text { Adj } R^{2} R^{2} \text { change } p\end{array}$ & $B \quad S E$ Adj $R^{2} R^{2}$ change $P$ & $B \quad S E$ Adj $R^{2} R^{2}$ change $p$ \\
\hline & $\begin{array}{llllll}-.50 & .08 & .13 & .13 & <.001\end{array}$ & $\begin{array}{lllll}-.26 & .09 & .03 & .03 & <.01\end{array}$ & $\begin{array}{llll}-.67 .09 & .001 & .17 & <.001\end{array}$ & $\begin{array}{llll}-.56 .10 & .09 & .09 & <.001\end{array}$ \\
\hline & Study engagement & Vigour & Dedication & Absorption \\
\hline & $B \quad S E$ AdjR $R^{2} R^{2}$ change $p$ & $B \quad S E$ AdjR $R^{2} R^{2}$ change $p$ & $B \quad S E \quad A_{d j} R^{2} R^{2}$ change $p$ & $B \quad S E$ AdjR $R^{2} R^{2}$ change $p$ \\
\hline Social skills & $.30 .07 .12 \quad .06<.001$ & $.28 .08 \quad .05 \quad .04<.001$ & $\begin{array}{lllll} & 46.08 & .16 & .001\end{array}$ & $\begin{array}{lllll} & .19 .08 & .09 & .02 & <.01\end{array}$ \\
\hline
\end{tabular}

Gender and age were used as control variables. $N=286$

Table 4. Linear Regression on the Association between Study Engagement and Burnout

\begin{tabular}{lccccl}
\hline & \multicolumn{5}{c}{ Study Burnout } \\
& $B$ & $S E$ & AdjR $^{2}$ & $R^{2}$ change & $p$ \\
\hline Model 1 & -.63 & .05 & .33 & .32 & $<.001$ \\
Model 2 & -.58 & .06 & .37 & .24 & $<.001$ \\
\hline
\end{tabular}

Model 1 - Gender and age were used as control variables, $\mathrm{N}=314$

Model 2 - Gender, age and social skills were used as control variables, $\mathrm{N}=286$

\section{Discussion and conclusion}

Our main finding shows associations between lower burnout and social skills and higher engagement and social skills among university students. Higher engagement was also related to lower burnout, thus corroborating earlier research.

Social skills seemed to play a role in study engagement, but from our knowledge, no study has examined the association between social skills and engagement among higher education students. Earlier research argued that social skills play a crucial role in student well- 
being (Buren \& Colen, 2010; Civitsi, 2015; Emadpoor et al., 2016; Malinauskas et al., 2014). Social skills promote social support (Cooley et al., 2010; Malinauskas et al., 2014; Riggio et al., 1990), which has been shown to promote school and classroom engagement (Kazan et al., 2017; Wang \& Eccles, 2012).

In line with previous research, social skills were connected to lower burnout (PereiraLima \& Loureiro, 2015). Earlier research maintained that impaired social skills are associated with burnout and depression in three different ways: poor social skills as a cause of depression, depression as a cause of poor social skills and poor social skills as a vulnerability factor in the development of depression (Segrin, 2000). Our study is cross-sectional and, thus, does not provide information on temporal relations. Further studies should examine this issue.

Social skills were also associated with the symptoms of burnout, that is, lower exhaustion, dedication and inefficacy. The largest association of these dimensions was between social skills and cynicism. Cynicism is naturally associated with social interaction and social relationships. Research indicates that cynicism is related to lower (Chen et al., 2016) and less sympathetic (Smith \& Frohm, 1985) social support. A cynical attitude also leads to social conflict and negative interaction (Kahler et al., 2012). Social skills were also connected to the dimensions of engagement. Vigour and absorption were associated with social skills, but dedication had the greatest association with the social skills of these dimensions. Dedication was closely associated with commitment, which promotes social relationships (Givertz, Segrin, \& Hanzal, 2009).

Social skills have been shown to increase psychological well-being by reducing depression and increasing life-satisfaction (Segrin et al., 2007), even though the impact on engagement and burnout has not yet been investigated. Social skills are associated with stress regulation; thus, poor social skills increase vulnerability to developing psychosocial stress (Luthar, 1991; Vinnick \& Erickson, 1994). These following associations should be more widely researched in the future: how does the level of social skills influence psychological stress, and how does stress, in turn, affect engagement and burnout?

Social transition into university is vital for student success in academic work and engagement and resilience is shown to promote transition into university and academic performance (Ayala \& Manzano, 2018). It has been suggested that integrating social learning spaces 
and practices like taking tutorials and demonstrations in a teaching programme would enhance students' social transition and study success (Kantanis, 2000; Matthews, Andrews, \& Adams, 2011). Social practices built on study programmes are shown to be helpful for students' social transition as well as for the quality of the learning environment. The quality of the learning environment comprises the following qualities: constructive teaching, support, teacher approachability, student and staff interaction, academic challenge, active learning, collaborative work, beyond-class collaboration and complementary activities (Coates, 2006). Coates (2006) proposes that as online learning plays a crucial role in university studies, the following issues should also be analysed: online engagement, online active learning, online academic relevance, online teaching, online collaboration, online social interaction and online contact with staff.

We also replicated the earlier research finding that higher engagement was associated with lower burnout in university students (Schaufeli et al., 2002). Our study supports the theory of defining engagement and burnout as parallel processes (Schaufeli \& Bakker, 2004). Study-related engagement is seen as buffering the risk of study-related burnout (Emadpoor et al., 2016; Civitsi, 2015). Previous research indicates of gender and age differences in engagement and burnout (Ayala \& Manzano, 2018; Liataert et al., 2015; Salmela-Aro et al., 2009). In the current study, we were able to take into account the potential effect of age and gender, as we controlled for them. Thus, we were able to get results on social skills and study engagement as well as on social skills and burnout that were independent of age and gender (i.e. not explained by gender or age).

\section{Educational implications}

Our findings are in line with those of earlier research showing that social skills play an important role in students' well-being, including many psychological indicators, and should be regarded in higher education. Our study shows that in addition to these previously found associations, social skills are also associated with higher study engagement and lower study burnout, which further corroborates the significance of social skills for students. Higher education practices should be built on pedagogic behaviour that supports group work and social skills such as collaborative and problem-based learning and practices (Ahlfeldt, Metha, \& Sellnow, 2005; Laal, 2013). 
These findings will prove useful for developing higher education and teaching methods aimed at increasing study engagement and decreasing the risk of study burnout. While social skills might present a framework for increasing study engagement and decreasing the risk of study burnout, further studies are needed before drawing definite conclusions.

\section{Limitations and strengths}

The most important limitation of the current study is the correlational design, which prevents the drawing of causal inferences. Other limitations concern the relatively small and homogenous sample and the use of self-report measures to assess social skills, engagement and burnout, which may lead to the common method variance problem (Podsakoff, MacKenzie, Lee, \& Podsakoff, 2003). Common method variance is not an automatic source of bias in self-report surveys, and its role may not be that significant, which has been suggested in the literature (Spector, 2006). Self-report surveys are still the best way to gather information about the subjectively experienced variables of engagement and burnout. There is also a need for other measurements, such as psychophysiological measures and longitudinal settings that would render greater validity to this study.

The survey used for assessing the students' social skills was non-standard, although it has been shown to have good reliability. Moreover, the theory and research behind the social skills survey has been widely used and tested for effectiveness in specific social skills training (Baker \& Daniels, 1989, 1990; Buser, 2008; Ivey, 1971; Ivey \& Ivey, 2007; Okun, 2002; Truax \& Carkhuff, 1967). The strengths of this study include the use of well-validated measures for study engagement and study burnout as well as a good research setting for our sample.

\section{Conclusions}

To summarise, this study provides insights into the role of social skills in the experience of engagement and burnout among university students. The findings support the importance of social skills and social support for students' well-being, defined in terms of engagement and burnout. The study also supports engagement and burnout as parallel processes. Paying attention to social interaction and social skills in university teaching might offer a way to increase students' engagement and to decrease the risk of burnout, although further studies are needed to support this recommendation. 


\section{References}

Ahlfeldt, S., Mehta, S., \& Sellnow, T. (2005). Measurement and analysis of student engagement in university classes where varying levels of PBL methods of instruction are in use. Higher Education Research \& Development, 24, 5-20. doi: $10.1080 / 0729436052000318541$

Ayala, J.C., \& Manzano, G. (2018). Academic performance of first-year university students: the influence of resilience and engagement. Higher Education Research \& Development, 27, 1321 - 1335. doi: 10.1080/0794360.2018.1502258

Baker, S., \& Daniels, T. (1989). Integrating Research on the Microcounseling Program: A Meta-Analysis. Journal of Counseling Psychology, 36, 213-222.

Baker, S., \& Daniels, T. (1990). Systematic Training of Graduate-level Counsellors: Narrative and Meta-Analytic Reviews of Three Major Programs. The Counseling Psychologist, $18,355-421$.

Bakx, A. A., Van Der Sanden, J. M., Sijitsma, K. K., Croon, M. A., \& Vermetten, Y. M. (2006). The Role of Students' Personality Characteristics, Self-Perceived Competence and Learning Conceptions in the Acquisition and Development of Social Communicative Competence: A Longitudinal Study. Higher Education, 51, 71-104. doi:10.1007/s10734-004-6377-6

Bilge, F., Dost, T., \& Cetin, B. (2014). Factors Affecting Burnout and Engagement among High School Students: Study Habits, Self-Efficacy Beliefs, and Academic Success. Educational Sciences: Theory and Practice, 14, 1721-1727. doi: 10.12738/estp.2014.5.1727

Bierman, K. L., \& Welsh, J. A. (2000). Assessing social dysfunction: the contributions of laboratory and performance-based measures. Journal of clinical child psychology, 29,4, 526-539. doi:10.1207/S15374424JCCP2904_6

Breso, E., Schaufeli, W., \& Salanova, M. (2010). Can a Self-Efficacy-Based Intervention Decrease Burnout, Increase Engagement, and Enhance Performance? A QuasiExperimental Study. Higher Education, 61, 339-355. doi:10.1007/s10734-010-9334-6

Buser, T. J. (2008). Counselor training: Empirical findings and current approaches. Counselor Education and Supervision, 48, 86. doi:10.1002/j.1556-6978.2008.tb00065.x

Cazan, A-M. (2015). Learning motivation, engagement and burnout among university students. Procedia - Social and Behavioral Sciences, 187, 413-417. doi: org/10.1016.j.sbspro.2015.03.077 
Chen, S. X., Lam, B. C. P W., Wu, C. H. Ng, J. C. K, Buchtel, E. E., Gaun, Y., \& Deng, H. (2016). Do People's World View Matter? The Why and How. Journal of Personality and Social Psychology, 110, 5, 743-765. doi:10.1037/pspp0000061

Civitsi, A. (2015). The Moderating Role of Positive and Negative Affect on the Relationship between Perceived Social Support and Stress in College Students. Education Sciences: Theory \& Practice, 15, 3, 565-573. doi:10.12738/estp.2015.3.2553

Cooley, E. L., Buren, A. V., \& Cole, S. P. (2011). Attachment Styles, Social Skills, and Depression in College Women. Journal of College Counseling, 13, 1, 50-62. doi:10.1002/j.2161-1882.tb00047.x

Dahlin, M., Juneborg, N., \& Runeson, B. (2007). Performance-Based Self-Esteem and Burnout in a Cross-Sectional Study of Medical Students. Medical Teacher, 29, 43-48. doi:10.1080/01421590601175309

Del Prette, Z. A. P., \& Del Prette, A. (2013). Social Skills Inventory (SSI-Del-Prette): Characteristics and Studies in Brazil. In Osório, F.L. (eds.) Social Anxiety Disorder 49-62. New York, NY: Nova Science.

Demaray, M. K., \& Elliot, S. N. (2001). Perceived Social Support by Children with Charasteristics of Attention-Deficit/Hyperactivity Disorder. School Psychology Quarterly 16, 6890. doi:10.1521/scpq.16.1.68.19156

Emadpoor, L., Lavasani, M. G., \& Shahcheraghi, S. M. (2016). Relationship between perceiced social support and psychological well-being among students based on mediating role of academic motivation. International Journal of Mental Health and Addiction, 14, 284-290. doi:10.1007/s11469-015-9608-4

Ford, M. E. (1982). Social Cognition and Social Competence in Adolescence. Developmental Psychology, 18(3), 323-340.

Forsyth, D. R., Lawrence, N. K., Burnette, J. L., \& Baumeister, R. F. (2007). Attempting to Improve Academic Performance of Struggling College Students by Bolstering their Self-Esteem: An Intervention that Backfired. Journal of Social and Clinical Psychology, 26, 447-459. doi:10.1521/jscp.2007.26.4.447

Friesen, D., \& Sarros, J. C. (1989). Sources of Burnout among Educators. Journal of Organizational Behaviour, 10(2), 179-188.

Gan, Y., Yang, M., Zhou, Y., \& Zhang, Y. (2007). The Two-Factor Structure of FutureOriented Coping and its Mediating Role in Student Engagement. Personality and individual Differences, 43, 851-863. doi:10.1016/j.paid.2007/02.009 
Givertz, M., Segrin, C., \& Hanzal, A. (2009). The Association between Satisfaction and Commitment Differs Across Marital Couple Types. Communication Research, 36, 561584. doi:10.1177/009365029333035

Galbraith, C. S., \& Merril, G. B. (2015). Academic Performance and Burnout: An Efficient Frontier Analysis of Resource Use Efficiency among Employed University Students. Journal of Further and Higher Education, 39, 2, 255-277. doi:10.1080/0309877X.2013.858673

Halbesleben, J. R. B., \& Buckley, M. R. (2006). Social Comparison and Burnout: The Role of Relative Burnout and Received Social Support. Anxiety, Stress, \& Coping, 19, 3, 259-278. doi:10.1080/10615800600747835

Ivey, A. E. (1971). Microcounseling: Innovations in Interviewing Training. Springfield, IL: Charles C Thomas.

Ivey, A. E., \& Ivey, M. B. (2007). International Interviewing and Counseling: Facilitating Client Development in a Multicultural Society. $6^{\text {th }}$ ed. Belmont, CA: Thomson Brooks/Cole.

Jacobs, S., \& Dodd, D. (2003). Student Burnout as a Function of Personality, Social Support, and Workload. Journal of College Student Development, 44, 291-303. doi:10.1353/csd.2003.0028

Kantanis, T. (2000). The Role of Social Transition in Students' Adjustment to the First Year of University. Journal of Institutional Research, 9(1), 100-110.

Kahler, C. W., McHugh, R. K., Leventhal, A. M., Colby, S. M., Gwaltney, C. J., \& Monti, M. P. (2012). High Hostility among Smokers Predicts Slower Recognition of Positive Facial Emotion. Personality and Individual Differences, 52, 444-448. doi:10.1016/j.paid.2011.11.009

Kiuru, N., Aunola, K., Nurmi, J.-E., Leskinen, E., \& Salmela-Aro, K. (2009). Peer group influence and selection in adolescents' school burnout: A longitudinal study. MerrillPalmer Quarterly, 54, 23-55. doi:10.1353/mpq.2008.0008

Kuh, G. F., Kinzie, J., Buckley, J., Bridges, B., \& Hayek, J.C. (2007). Piecing Together the Student Success Puzzle: Research, Propositions, and Recommendations. ASHE Higher Education Report, 32, 5. doi:10.1002/aehe.3205

Kutsal, D., \& Bilge, F. (2012). A Study on the Burnout and Social Support Levels of High School Students. Education and Science, 37, 164.

Laal, M. (2013). Positive Interdependence in Collaborative Learning. Procedia - Social and Behavioural Sciences, 93, 1433-1437. doi:10.1016/j.sbspro.2013.10.058 
Lamonte, D., Currie, F. Alisat, S., Sullivan, T., Pratt, M., Pancer, S., \& Hunsberger, B. (1995). Impact of a Social Support Intervention on the Transition to University. Journal of Community Mental Health, 14, 167-180. doi:10.7870/cjcmh-1995-0023

Liataert, S., Roorda, D., Laevers, F., Verschueren, K., \& De Fraine, B. (2015). The gender gap in student engagement: The role of teachers' autonomy support, structure, and involvement. The British Journal of Educational Psychology, 85, 498-518. doi: 10.1111/bjep.12095

Lyndon, M., Henning, P., Alyami, M. A., Krishna, H., Zeng, S., Yu, I., \& Hill, T. C. (2017). Burnout, quality of life, motivation and academic achievement among medical students: A person-oriented approach. Perspectives on Medical Education, 6, 108-114. doi:10.1007/s40037-017-0340-6.

Luthar, S. S. (1991). Vulnerability and Resilience: A Study of High-Risk Adolescents. Child Development, 62, 600-616. doi:10.1111/j.1467-8624.1991.tb01555.x

Malinauskas, R., Dumciene, A., \& Lapeniene, D. (2014). Social Skills and Life Satisfaction of Lithuanian First- and Senior-Year University Students. Social Behaviour and Personality, 42, 285-294. doi:10.2224/sbp.2014.42.2.285

Maslach, C., \& Leiter, M.P. (2005). Stress and Burnout: The Critical Research. In Cooper, C.L. (eds.) Handbook of Stress Medicine and Health. ( $2^{\text {nd }}$ ed.). London: CRC Press.

Maslach, C., Schaufeli, W., \& Leiter, M. (2001). Job Burnout.” Annual Review of Psychology, 52, 397-422. doi:10.1146/annurev.psych.52.1.397

Matthews, K.E., Andrews, V., \& Adams, P. (2011). Social learning spaces and student engagement. Higher Education Research \& Development 30, 105-120. doi:10.1080/07294360.2010.512629

Meriläinen, M., \& Kuittinen, M. (2014). The Relation between Finnish University Students' Perceived Level of Study-related Burnout, Perceptions of the Teaching-Learning Environment and Perceived Achievement Motivation. Pastoral Care in Education, 32, 186196. doi:10.1080/02643944.2014.893009

Mostert, K., Pienaar, J., Gauche, C., \&Jackson. L. T. B. (2007). Burnout and Engagement in University Students: A Psychometric Analysis of the MBI-SS and UWES-S. South African Journal of Higher Education, 21(1), 147-162.

Okun. B. (2002). Effective Helping. Interviewing and Counseling Techniques. (6 $6^{\text {th }}$ ed.) Pacific Grove: Thomson Books/Cole. 
Pereira-Lima, K., \&. Loureiro, S. R. (2015). Burnout, Anxiety, Depression, and Social Skills in Medical Residents. Psychology, Health \& Medicine, 20, 353-362. doi:10.1080/13548506.2014.936889

Podsakoff, P. M., MacKenzie, S. B., Lee, J. Y., \& Podsakoff, N. P. (2003). Common Method Biases in Behavioral Research: A Critical Review of the Literature and Recommended Remedies. Journal of Applied Psychology, 88, 879-903. doi:10.1037/00219010.88.5.879

Pomerantz, E. M., Altermatt, E. R., \& Saxon, J. L. (2002). Making the grade but feeling distressed: Gender differences in academic performance and internal distress. Journal of Educational Psychology, 94, 396-404. doi:10.1037/0022-0663.94.2.396

Reiseberg, L. (2000). Student stress is rising, especially among young women. Chronicle of Higher Education, 46(21), 49-50.

Riggio, R., Throckmorton, N., \& DePaola, S. (1990). Social Skills and Self-Esteem. Personality and Individual Differences, 11, 799-804. doi:10.1016/0191-8869(90)90188-W

Riggio, R., \& Zimmerman, J. (1991). Social Skills and Interpersonal Relationships: Influences on Social Support and Support Seeking. In Jones, W. H. \& Perlman, D. W. (eds.) Advances in Personal Relationships, 133-155. London: Jessica Kingsley.

Robins, T. G., Roberts, R. M., \& Sarris, A. (2018). The role of student burnout in predicting future burnout: exploring the transition from university to the workplace. Higher Education Research \& Development 37, 115-130. doi: 10.1080/07294360.2017.1344827

Rodriguez-Hidalgo, A. J., Calmaestra, J., \& Dios, I. (2014). Burnout and Competency development in pre-Service Teacher Training. Electronic Journal of Research in Educational Psychology, 34, 649 - 670. doi: 10.14204/ejrep.34.14048

Salmela-Aro, K., Kiuru, N., Leskinen, E., \& Nurmi, J-E. (2009). School Burnout Inventory (SBI). Reliability and Validity. European Journal of Psychological Assessment, 25, 4857. doi:10.1027/1015-5759.25.1.48

Salmela-Aro, K., \& Kunttu, K. (2010). Study Burnout and Engagement in Higher Education. Unterrichtswissenschaft, 38, 318-333.

Salmela-Aro, K., Savolainen, H., \& Holopainen, L. (2009). Depressive Symptoms and School Burnout during Adolescence: Evidence from Two Cross-Lagged Longitudinal Studies. Journal of Youth Adolescence, 38, 1316-1327. doi:10.1007/s10964-008-9334-3

Salmela-Aro, K., \& Updyaya, K. (2014). School Burnout and Engagement in the Context of Demands-Resources Model. British Journal of Educational Psychology, 84, 137-151. doi:10.1111/bjep.12018 
Salanova, M., Schaufeli, W., Martinez, I., \& Breso, E. (2010). How Obstacles and Facilitators Predict Academic Performance: The Mediating Role of Study Burnout and Engagement. Anxiety, Stress \& Coping, 23, 53-70. doi:10.1080/10615800802609965

Schaufeli, W. B., \& Salanova, M. (2007). Efficacy of Inefficacy, that's the Question: Burnout and Engagement, and their relationships with efficacy beliefs. Anxiety, Coping \& Stress, 20, 177-196. doi: 10.1080/10615800701217878

Schaufeli, W. B., \& Bakker, A. (2004). Job Demands, Job Resources, and their Relationship with Burnout and Engagement: A Multi-Sample Study. Journal of Organizational Behavior, 25, 293-315. doi: 10.1002/job.248

Schaufeli, W. B., Martinez, I., Pinto, A., Salanova, M., \& Bakker, A. (2002). Burnout and Engagement in University Students: A Cross-national Study. Journal of Cross-Cultural Psychology, 33, 264-481. doi:10.1177/0022022102033005003

Schaufeli, W., Salanova, M., Gonzales-Roma, V., \& Bakker, A. (2002). The Measurement of Engagement and Burnout: A Confirmative Analytic Approach. Journal of Happiness Studies, 3, 71-92. doi:10.1023/A:1015630930326

Schouweburg, H.C. (2004). Procrastination in Academic Settings: General Introduction. In Schouwenburg, H. C., Pychyl, T. A., \& Ferrari, J. R. (eds.) Counseling the Procrastinator in Academic Settings, 91-106. Washington DC: American Psychological Association.

Schutte, N., Toppinen, S., Kalimo, R., \& Schaufeli, W. (2000). The factorial validity of the Maslach Burnout Inventory-General Survey (MBI-GS) across occupational groups and nations. Journal of Occupational and Organizational Psychology, 73, 53-66. doi: $10.1348 / 096317900166877$

Schöne, C., Tandler, S., \& Stiendmeier-Pelster, J. (2015). Contingent self-esteem and vulnerability to depression: academic contingent self-esteem predicts depressive symptoms in students. Frontier in Psychology, 20(6), doi:10.3389/fpsyg.2015.01573

Segrin, C. (2000). Social Skills Deficits Associated with Depression. Clinical Psychology Review, 20, 379-403. doi:10.1016/s0272-7358(98)00104-4

Segrin, C. (1993). Social Skills Deficits and Psychosocial Problems: Antecedent, Concomitant, or Consequent? Journal of Social and Clinical Psychology, 12, 336-353. doi:10.1521/jscp.1993.12.3.336

Siedlecki, K., Salthouse, K., Oishi, T. A., \& Jeswani, S. (2014). The relationship Between Social Support and Subjective Well-Being Across Age. Social Indicators Research, 117, 561- 576. doi:10.1007/s11205-013-0361-4 
Smith, T. W., \& Frohm, K. D. (1985). What's so Unhealthy about Hostility? Construct Validity and Psychosocial Correlates of the Cook and Medley Ho Scale. Health Psychology, 4, 503-520. doi:10.1037/0278-6133.4.6.503

Spence, S. H. (2003). Social Skills Training with Children and Young People: Theory, Evidence and Practise. Child and Adolescent Mental Health, 8, 84-96. doi:19.1111/14753588.00051

Stoeber, J., Childs, J. H., Hayward, J .A., \& Feast, A. R. (2010). Passion and Motivation for Studying: Predicting Academic Engagement and Burnout in University Students. Educational Psychology, 31, 513-528. doi:10.1080/01443410.2011.570251

Truax, C. C., \& Clarhuff, R. R. (1976). Toward effective counselling and psychotherapy. Chigago: Aldine.

Uludag, O., \& Yaratan, H. (2010). The Effect of Burnout on Engagement: An Empirical Study on Tourism Students. Journal of Hospitality, Leisure, Sport \& Tourism Education, 9, 13-23. doi:10.3794/johlste.91.243

Vizoso, C. Rodriguez, C., \& Arias-Gundin, O. (2018). Coping, academic engagement and performance in university students. Higher Education Research \& Development 37, 1515-1529. doi:10.1080/07294360-2018.1504006

Wang, M., \& Eccles, J. (2012). Social Support Matters: Longitudinal Effects of Social Support on Three Dimensions of School Engagement from Middle to High School. Child Development, 83, 877-895. doi:10.1111/j.1467-8624.2012.01745.x

Zach, S., Yazdi-Ugav, O., \& Zeev, A. (2016). Academic Achievements, Behavioral Problems and Loneliness as Predictors of Social Skills among Student with and without Learning Disorders. School Psychology International, 37, 378-396. doi: $10.1177 / 0143034316649231$

Zhang, Y., Gan, Y., \& Cham, H. (2007). Perfectionism, Academic Burnout and Engagement among Chinese College Students: A Structural Equation Modeling Analysis. Personality and Individual Differences, 43, 1529-1540. doi:10.1016/j.paid.2007.04.010

Received: $19-09-2019$

Accepted: 04-12-2019 